\title{
GAMBARAN FIGUR OTORITAS TERHADAP KEPATUHAN PERAWAT DALAM IMPLEMENTASI STANDAR PROSEDUR OPERASIONAL KEBERSIHAN TANGAN
}

\author{
Description of Authority Figure on Nursing Obedience in Implementation \\ Standard Operational Procedure of Hand Hygiene
}

Amira Maulida Putri

PERSAKMI Jawa Timur, Indonesia

E-mail: amira.maulida.putri-2014@fkm.unair.ac.id

\begin{abstract}
Background: Nurses' obedience in the implementation of Standard Operational Procedures of hand hygiene is an effort in preventing phlebitis in the hospital. Report on surveillance data by Infection Prevention and Control or Pencegahan dan Pengendalian Infeksi (PPI) RSUD Dr. R. Sosodoro Djatikoesoemo Bojonegoro 2017 mentioned the incidence of phlebitis in the Inpatient Installation reached $2.73 \%$. One cause of high rates of phlebitis is incorrect nurse's hand-washing technique according to the procedures.

Aim: This study aimed to analyze the relationship between status of location from RSUD Dr. R. Sosodoro Djatikoesoemo Bojonegoro, personal responsibility, legitimacy, status, and proximity of authority figures and nurses' obedience to Standards Operational Procedures of hand hygiene before and after intravenous installation. Method: This study was an analytical study with a cross-sectional framework. This study was conducted in April 2018 at in-patient installation of RSUD Dr. R. Sosodoro Djatikoesoemo Bojonegoro by inviting 52 nurses chosen with stratified random sampling.

Results: It was found that there was a significant correlation between personal responsibility $(p=0.020)$, status $(0.015)$ and proximity of authority figure $(p=0.000)$ and nurses' obedience to the implementation of Standards Operational Procedures of hand hygiene before and after intravenous installation in in-patient installation of RSUD Dr. R. Sosodoro Djatikoesoemo Bojonegoro.

Conclusion: It can be concluded that the majority of the nurses did not follow hand hygiene stages well. The hospital needs to improve nurses' personal responsibility, authority figure status, and rapport of authority figure.
\end{abstract}

Keywords: hand hygiene, nurse obedience, Standard Operational Procedures

\section{ABSTRAK}

Latar Belakang: Kepatuhan perawat dalam implementasi Standar Prosedur Operational (SPO) kebersihan tangan atau hand hygiene merupakan salah satu upaya dalam mencegah terjadinya phlebitis di rumah sakit. Data Laporan Surveilans Komite Pencegahan dan Pengendalian Infeksi (PPI) RSUD Dr. R. Sosodoro Djatikoesoemo Bojonegoro tahun 2017 menyebutkan bahwa angka kejadian phlebitis di Instalasi Rawat Inap (IRNA) mencapai $2,73 \%$. Salah satu penyebab tingginya angka phlebitis adalah teknik cuci tangan perawat yang tidak sesuai dengan prosedur yang telah ditetapkan oleh rumah sakit.

Tujuan: Penelitian ini bertujuan untuk menganalisis hubungan status lokasi dari RSUD Dr. R. Sosodoro Djatikoesoemo Bojonegoro, tanggung jawab personal, legitimasi figur otoritas, status figur otoritas, dan kedekatan figur otoritas dengan kepatuhan perawat dalam implementasi SPO kebersihan tangan sebelum dan sesudah pemasangan infus.

Metode: Penelitian ini merupakan penelitian analitik dengan rancang bangun penelitian cross-sectional. Penelitian dilakukan pada bulan April 2018 di Instalasi Rawat Inap RSUD Dr. R. Sosodoro Djatikoesoemo Bojonegoro dengan melibatkan 52 perawat yang dipilih berdasarkan stratified random sampling.

Hasil: Berdasarkan hasil penelitian dapat disimpulkan bahwa terdapat hubungan yang signifikan antara tanggung jawab personal $(p=0,020)$, status figur otoritas $(0,015)$ dan kedekatan figur otoritas $(p=0,000)$ dengan kepatuhan perawat dalam implementasi Standar Prosedur Operasional (SPO) kebersihan tangan sebelum dan sesudah pemasangan infus di Instalasi Rawat Inap (IRNA) RSUD Dr. R. Sosodoro Djatikoesoemo Bojonegoro.

Kesimpulan: Dapat disimpulkan bahwa sebagian besar perawat tidak mengikuti tahap cuci tangan dengan baik. Rumah sakit perlu meningkatkan kewajiban personal perawat, status figure otoritas, dan kedekatan figur otoritas.

Kata Kunci: kebersihan tangan, kepatuhan perawat, Standar Prosedur Operasional

\begin{tabular}{lrr}
\hline Received: 7 June 2018 & Accepted: 13 August 2018 & Published: 1 December 2018 \\
PENDAHULUAN & Menurut & Peraturan Menteri Kesehatan
\end{tabular}


indikator Sasaran Keselamatan Pasien, salah satunya adalah pengurangan risiko infeksi terkait pelayanan kesehatan. Kejadian HealthcareAssosiated Infections (HAl's) merupakan salah satu masalah yang dapat mengancam keselamatan pasien maupun tenaga kesehatan serta keluarga pasien. Oleh karena itu, penting bagi rumah sakit untuk menerapkan program dalam mencegah kejadian Healthcare-Assosiated Infections (HAls). Kejadian Healthcare-Assosiated Infections (HAls). Yang paling sering terjadi di fasilitas pelayanan kesehatan adalah infeksi nafas bagian bawah, infeksi saluran kemih, infeksi luka operasi, dan phlebitis (Depkes RI, 2003).

Phlebitis merupakan peradangan akut yang terjadi pada lapisan internal vena dimana ditandai ditandai dengan rasa nyeri di sepanjang pembuluh vena serta terjadi kemerahan, bengkak dan hangat yang dapat dirasakan di sekitar daerah penusukan (Nursalam, 2014). Bacterial Phlebitis disebabkan oleh bakteri yang masuk ke dalam pembuluh vena, sehingga dapaat memicu respon inflamasi pada daerah penyisipan cannula yang diikuti dengan pembentukan koloni bakteri. Praktik yang buruk selama pemberian obat, frekuensi pemberian obat tinggi dan praktek cuci tangan yang buruk sebelum penyisipan cannula dalam pemasangan infus (Infusion Nursing Society, 2016)

RSUD Dr. R. Sosodoro Djatikoesoemo Bojonegoro merupakan rumah sakit kelas B Non Pendidikan yang berdiri sejak tahun 1928. Data Laporan Surveilans Komite Pencegahan dan Pengendalian Infeksi (PPI) RSUD Dr. R. Sosodoro Djatikoesoemo Bojonegoro tahun 2017 menyebutkan bahwa angka kejadian Phlebitis di Instalasi Rawat Inap (IRNA) mencapai 2,73\%. Angka kejadian Phlebitis tersebut tergolong tinggi karena belum mencapai target yang ditetapkan oleh rumah sakit yaitu $<0,5 \%$. Hasil analisis yang dilakukan oleh Komite PPI RSUD Dr. R. Sosodoro Djatikoesoemo Bojonegoro menyebutkan bahwa salah satu faktor yang paling dominan menjadi penyebab tingginya angka kejadian Phlebitis adalah teknik kebersihan tangan yang dilakukan oleh perawat belum dilakukan secara menyeluruh berdasarkan Standar Prosedur Operasional (SPO) yang telah ditetapkan. Selain itu, data Laporan Audit Hand Hygiene tahun 2017 menyebutkan bahwa angka kepatuhan perawat dalam melakukan Hand Hygiene (kebersihan tangan) adalah 56,41\%, angka tersebut belum mencapai target yang telah ditetapkan oleh rumah sakit sebesar $>80 \%$.

Program keselamatan pasien merupakan salah satu upaya yang dapat dilakukan rumah sakit dalam mengendalikan HAl's serta berguna dalam peningkatan mutu pelayanan kesehatan (Depkes, 2010). Salah satu upaya keselamatan pasien yang dapat dilakukan rumah sakit untuk menekan angka kejadian Phlebitis di Instalasi Rawat Inap (IRNA) adalah menerapkan Standar Prosedur Operasional (SPO) kebersihan tangan (Hand Hygiene) sebelum dan sesudah pemasangan infus. Sehingga dapat menggambarkan tingkat kepatuhan perawat dalam melakukan kebersihan tangan sebelum dan sesudah pemasangan infus. Kebersihan tangan atau Hand Hygiene adalah upaya atau tindakan yang berhubungan dengan kebersihan tangan dan dapat dilakukan dengan 2 cara yaitu menggunakan sabun antiseptik di dengan air mengalir atau menggunakan cairan antiseptic berbasis alkohol (handrub) sesuai dengan langkah-langkah secara sistematik berdasarkan urutan, sehingga dapat mengurangi jumlah bakteri yang kemungkinan berada pada tangan (Asiye Akyol, 2007).

Berdasarkan masalah penelitian tersebut, maka penelitian ini bertujuan untuk menganalisis faktor yang berhubungan dengan kepatuhan perawat dalam implementasi Standar Prosedur Operasional (SPO) kebersihan tangan sebelum dan sesudah pemasangan infus berdasarkan teori kepatuhan milgram antara lain persepsi perawat tentang status lokasi, tanggung jawab personal, legitimasi figur otoritas, status figur otoritas, dan kedekatan figur otoritas di Instalasi Rawat Inap (IRNA) RSUD Dr. R. Sosodoro Djatikoesoemo Bojonegoro.

\section{METODE}

Penulisan artikel ilmiah ini menggunakan metode penelitian analitik untuk mencari hubungan variabel independen dengan variabel dependen dengan rancang bangun penelitian cross-sectional karena subyek penelitian diobservasi sebanyak satu kali pada waktu tertentu tanpa memberikan intervensi. Variabel independen dalam penelitian ini adalah status lokasi, tanggung jawab personal, legitimasi figur otoritas, status figur otoritas, dan kedekatan figur otoritas, sedangkan variabel dependen adalah kepatuhan perawat dalam implementasi SPO kebersihan tangan sebelum dan sesudah pemasangan infus.

Penelitian ini dilakukan pada bulan April 2018 di Instalasi Rawat Inap (IRNA) RSUD Dr. R. Sosodoro Djatikoesoemo Bojonegoro yaitu Ruang Ruang Jantung, Paru, Syaraf, Penyakit Dalam, Bedah, Anak, NICU, VIP Anggrek dan VVIP Wijaya Kusuma. Populasi dalam penelitian ini adalah seluruh perawat di Instalasi Rawat Inap (IRNA) RSUD Dr. R. Sosodoro Djatikoesoemo Bojonegoro yaitu sebesar 134 perawat. Perhitungan sampel dilakukan secara probability sampling dengan teknik stratified random sampling diperoleh 52 perawat. Kriteria inklusi dalam penelelitian ini adalah Perawat pelaksana di Instalasi Rawat Inap (IRNA), tidak memiliki jabatan sebagai Kepala Ruangan, sudah bekerja minimal 1 tahun dan tidak berstatus sebagai karyawan magang.

Teknis analisis data pada penelitian menggunakan aplikasi komputer uji statistic (SPSS) yaitu uji Chi Square untuk menganalisis apakah terdapat hubungan antara status lokasi, tanggung jawab personal, legitimasi figur otoritas, status figur otoritas, dan kedekatan figur otoritas dengan kepatuhan perawat dalam implementasi Standar Prosedur Operasional (SPO) kebersihan tangan sebelum dan sesudah pemasangan infus. Pengambilan data dilakukan dengan cara menyebarkan kuesioner dan melakukan observasi kepada perawat sebagai responden. Tedapat skala likert 1-4 pada kuesioner penelitian yang selanjutnya akan diskoring pada masing-masing variabel untuk setiap responden. Kemudian hasil 
skoring tersebut akan dimasukkan pada aplikasi uji statistik untuk menganalisis hubungan variabel independen dengan variabel dependen menggunakan uji statistik Chi Square.

\section{HASIL DAN PEMBAHASAN}

Hasil penelitian yang dilakukan di Instalasi Rawat Inap RSUD Dr. R. Sosodoro Djatikoesoemo Bojonegoro tentang gambaran figur otoritas terhadap kepatuhan perawat dalam implementasi Standar Prosedur Operasional kebersihan tangan pada tiap variabel dapat dilihat pada Tabel 1. Hasil skoring pada Tabel 1 menunjukkan bahwa sebagian besar perawat memiliki persepsi yang baik tentang status lokasi, tanggung jawab personal, legitimasi figur otoritas dan kedekatan figur otoritas. Sedangkan dalam variabel status figur otoritas, perawat memiliki persepsi yang cukup.

\section{Status Lokasi}

Penilaian status lokasi meliputi persepsi perawat terhadap prestige RSUD Dr. R. Sosodoro Djatikoesoemo Bojonegoro sehingga berkaitan dengan rasa bangga perawat dan pengetahuan perawat terhadap prestasi yang telah dicapai oleh RSUD Dr. R. Sosodoro Djatikoesoemo Bojonegoro.

Berdasarkan Tabel 1 didapatkan hasil bahwa sebagian besar $(61,5 \%)$ perawat memiliki penilaian prestige yang baik terhadap status lokasi RSUD Dr. R. Sosodoro Djatikoesoemo Bojonegoro. Hal tersebut menunjukkan bahwa perawat memiliki rasa bangga terhadap prestasi maupun citra baik dari RSUD Dr. R. Sosodoro Djatikoesoemo Bojonegoro.

Tabel 1. Hasil Skoring Tiap Varibel di Instalasi Rawat Inap (IRNA) RSUD Dr. R. Sosodoro Djatikoesoemo Bojonegoro tahun 2018

\begin{tabular}{lccc}
\multirow{2}{*}{ Variabel } & \multicolumn{3}{c}{ Kategori } \\
\cline { 2 - 4 } & $\begin{array}{c}\text { Kurang } \\
(\%)\end{array}$ & $\begin{array}{c}\text { Cukup } \\
(\%)\end{array}$ & $\begin{array}{c}\text { Baik } \\
(\%)\end{array}$ \\
\hline Status Lokasi & 2,0 & 36,5 & 61,5 \\
\hline Tanggung Jawab Personal & 0,0 & 26,9 & 73,1 \\
\hline Legitimasi Figur Otoritas & 0,0 & 48,1 & 51,9 \\
\hline Status Figur Otoritas & 0,0 & 55,8 & 44,2 \\
\hline Kedekatan Figur Otoritas & 13,4 & 40,4 & 46,2
\end{tabular}

\section{Tanggung Jawab Personal}

Penilaian tanggung jawab personal berkaitan dengan tanggung jawab perawat dalam implementasi setiap tindakan dan langkah kebersihan tangan sebelum dan sesudah pemasangan infus sesuai dengan Standar Prosedur Operasional (SPO) Kebersihan Tangan yang telah ditetapkan oleh rumah sakit.

Berdasarkan Tabel 1 didapatkan hasil bahwa sebagian besar $(73,1 \%)$ perawat memiliki tanggung jawab yang baik dalam implementasi Standar Prosedur Operasional (SPO) kebersihan tangan sebelum dan sesudah pemasangan infus di Instalasi Rawat Inap (IRNA) RSUD Dr. R. Sosodoro Djatikoesoemo Bojonegoro.

\section{Legitimasi Figur Otoritas}

Penilaian legitimasi figur otoritas berkaitan dengan persepsi perawat terhadap kepala ruangan yang dianggap sesuai dengan jabatan sah yang dimiliki sehingga legal dan berhak untuk mengatur dan memberikan kewenangan serta perintah kepada perawat untuk melakukan sesuatu sesuai dengan prosedur yang ditetapkan.

Berdasarkan Tabel 1 didapatkan hasil bahwa sebagian besar $(51,9 \%)$ perawat menilai bahwa kepala ruangan merupakan figur otoritas yang sah atau legal dalam mengatur dan memberikan perintah kepada perwat dalam melaksanakan Standar Prosedur Operasional (SPO) kebersihan tangan sebelum dan sesudah pemasangan infus di Instalasi Rawat Inap (IRNA) RSUD Dr. R. Sosodoro Djatikoesoemo Bojonegoro.

\section{Status Figur Otoritas}

Penilaian status figur otoritas berkaitan dengan persepi perawat terhadap keterampilan, kemampuan, pengetahuan dan profesionalitas kepala ruangan di rumah sakit.

Berdasarkan Tabel 1 didapatkan hasil bahwa sebagian besar $(55,8 \%)$ perawat memiliki persepsi yang cukup bahwa kepala ruangan merupakan figur otoritas yang meimiliki ketrampilan, kemampuan dan pengetahuan yang baik dalam penerapan Standar Prosedur Operasional (SPO) kebersihan tangan di Instalasi Rawat Inap (IRNA) RSUD Dr. R. Sosodoro Djatikoesoemo Bojonegoro.

\section{Kedekatan Figur Otoritas}

Penilaian kedekatan figur otoritas berkaitan dengan persepsi perawat terhadap kedekatan hubungan yang terjalin antara perawat dengan kepala ruangan dalam implementasi SPO Hand Hygiene sebelum dan sesudah pemasangan infus. Berdasarkan Tabel 1 didapatkan hasil bahwa sebagian besar $(46,2 \%)$ perawat menganggap bahwa kepala ruangan memiliki kedekatan yang baik dengan perawat di Instalasi Rawat Inap (IRNA) RSUD Dr. R. Sosodoro Djatikoesoemo Bojonegoro.

\section{Kepatuhan Perawat dalam Implementasi SPO Kebersihan Tangan Sebelum dan Sesudah Pemasangan Infus}

Hand Hyigiene merupakan istilah umum yang digunakan untuk menyatakan kegiatan yang berkaitan dengan membersihkan tangan (WHO 2009). Menurut (Asiye Akyol, 2007) Kebersihan tangan adalah upaya atau tindakan yang berhubungan dengan kebersihan tangan yang dapat dilakukan dengan 2 cara yaitu menggunakan sabun dengan air mengalir atau menggunakan cairan antiseptik berbasis alkohol (handrub) sesuai dengan langkah-langkah secara sistematik berdasarkan urutan yang bertujuan untuk mengurangi jumlah bakteri yang kemungkinan berada pada tangan.

Kepatuhan perawat dalam implementasi Standar Prosedur Operasional (SPO) kebersihan tangan sebelum dan sesudah pemasangan infus dalam penelitian ini diukur dengan melakukan penilaian terhadap kegiatan perawat dalam mengimplementasikan kebersihan tangan sebelum dan sesudah pemasangan infus sesuai dengan 
urutan langkah yang terdapat pada Standar Prosedur Operasional (SPO) kebersihan tangan yang telah ditetapkan oleh RSUD Dr. R. Sosodoro Djatikoesoemo Bojonegoro.

Tabel 2. Hasil Skoring Kepatuhan Perawat dalam Implementasi Standar Prosedur Operasional (SPO) Kebersihan Tangan Sebelum dan Sesudah Pemasangan Infus di IRNA RSUD Dr. R. Sosodoro Djatikoesoemo Bojonegoro tahun 2018

\begin{tabular}{lcc}
$\begin{array}{c}\text { Kepatuhan } \\
\text { Perawat }\end{array}$ & Frekuensi & $\begin{array}{c}\text { Persentase } \\
(\%)\end{array}$ \\
\hline Patuh & 23 & 44,2 \\
\hline Tidak Patuh & 29 & 55,8 \\
\hline Total & 52 & 100,0
\end{tabular}

Tabel 2 menunjukkan bahwa mayoritas perawat $(55,8 \%)$ tidak patuh dalam implementasi Standar Prosedur Operasional (SPO) Kebersihan Tangan sebelum dan sesudah pemasangan infus di Instalasi Rawat Inap (IRNA) RSUD Dr. R. Sosodoro Djatikoesoemo Bojonegoro tahun 2018. Hal tersebut dikarenakan pada saat melakukan kebersihan tangan sebelum dan sesudah pemasangan infus, perawat cenderung tidak melakukan seluruh langkah kebersihan tangan sesuai dengan Standar Prosedur Operasional (SPO) yang telah ditetapkan oleh rumah sakit.

Berdasarkan hasil penelitian pada Tabel 3 diketahui bahwa sebagian besar perawat tidak mematuhi 6 langkah cuci tangan yang ada dalam Standar Prosedur Operasional (SPO) kebersihan tangan yang telah ditetapkan oleh rumah sakit. Hasil penilaian yang rendah dalam implementasi 6 langkah cuci tangan adalah langkah ke-4 yaitu menggosok punggung jari-jari pada telapak yang berlawan dengan jari-jari saling mengunci $(57,7 \%)$, langkah ke-5 yaitu menggosok secara memutar pada ibu jari kiri dengan tangan kanan mengunci pada ibu jari tangan kiri dan sebaliknya $(37,5 \%)$ dan langkah ke-6 yaitu menggosok ujung kuku jari kiri secara memutar pada telapak tangan kanan dan sebaliknya $(25,9 \%)$. Hal tersebut menunjukkan bahwa sebagian besar perawat tidak melakukan langkah kebersihan tangan dengan sempurna sesuai dengan Standar Prosedur Operasional (SPO).

Tabel 3. Persentase Hasil Penilaian kepatuhan perawat dalam melakukan setiap langkah Kebersihan Tangan berdasarkan Standar Prosedur Operasional kebersihan tangan sebelum dan sesudah pemasangan infus di IRNA RSUD Dr. R. Sosodoro Djatikoesoemo Bojonegoro tahun 2018

\begin{tabular}{|c|c|c|c|c|}
\hline \multirow{2}{*}{ No } & \multirow{2}{*}{ Langkah Kebersihan Tangan } & \multicolumn{2}{|c|}{ Hasil Penilaian } & \multirow{2}{*}{$\begin{array}{l}\text { Rata-rata } \\
\text { (\%) }\end{array}$} \\
\hline & & Sebelum (\%) & Sesudah(\%) & \\
\hline 1. & $\begin{array}{l}\text { Melakukan tindakan kebersihan tangan dengan: } \\
\text { a. sabun dan air mengalir atau, } \\
\text { b. cairan antiseptik berbasis alkohol (Handrub) }\end{array}$ & 92,3 & 95,20 & 93,7 \\
\hline 2. & $\begin{array}{l}\text { a. Membasahi tangan menggunakan air mengalir dan } \\
\text { menuangkan sabun kurang lebih } 5 \mathrm{cc} \text { atau, } \\
\text { b. Menuangkan } 3-5 \mathrm{ml} \text { larutan antiseptik berbasis alkohol } \\
\text { pada telapak tangan }\end{array}$ & 92,3 & 95,2 & 93,7 \\
\hline 3. & $\begin{array}{l}\text { Meratakan sabun atau larutan antiseptik berbasis alkohol } \\
\text { pada telapak tangan secara menyeluruh }\end{array}$ & 92,3 & 95,2 & 93,7 \\
\hline \multirow[t]{2}{*}{4.} & $\begin{array}{l}\text { Melakukan } 6 \text { langkah cuci tangan: } \\
\text { 1) Menggosok tangan dengan posisi telapak pada telapak }\end{array}$ & 92,3 & 95,2 & 93,7 \\
\hline & $\begin{array}{l}\text { 2) Menggosok telapak tangan kanan diatas punggung } \\
\text { tangan kiri dengan jari-jari yang saling menjalin dan } \\
\text { sebaliknya }\end{array}$ & 82,7 & 85,6 & 84,1 \\
\hline & $\begin{array}{l}\text { 3) Menggosok kedua telapak tangan dan jari-jari saling } \\
\text { menjalin }\end{array}$ & 76,0 & 75,0 & 75,5 \\
\hline & $\begin{array}{l}\text { 4) Menggosok punggung jari-jari pada telapak yang } \\
\text { berlawanan dengan jari-jari saling mengunci }\end{array}$ & 54,8 & 60,6 & 57,7 \\
\hline & $\begin{array}{l}\text { 5) Menggosok secara memutar pada ibu jari kiri dengan } \\
\text { tangan kanan mengunci pada ibu jari tangan kiri dan } \\
\text { sebaliknya }\end{array}$ & 32,7 & 42,3 & 37,5 \\
\hline & $\begin{array}{l}\text { 6) Menggosok ujung kuku jari kiri secara memutar pada } \\
\text { telapak tangan kanan dan sebaliknya }\end{array}$ & 24,0 & 27,9 & 25,9 \\
\hline 5. & $\begin{array}{l}\text { a. Membilas tangan menggunakan air mengalir dan } \\
\text { mengeringkan kedua tangan secara menyeluruh } \\
\text { menggunakan tisu serta menutup kran menggunakan } \\
\text { tisu } \\
\text { b. Mengeringkan kedua tangan }\end{array}$ & 79,8 & 77,9 & 78,8 \\
\hline & $\begin{array}{l}\text { Perawat yang tidak patuh dalan } \\
\text { nentasi SPO kebersihan tangan sebelum da }\end{array}$ & $\begin{array}{l}\text { uci tangan, se } \\
\text { ekerjaan yang } \\
\text { aan pasien yar }\end{array}$ & $\begin{array}{l}\text { in itu peraw } \\
\text { harus seg€ } \\
\text { gawat dan }\end{array}$ & $\begin{array}{l}\text { empunyai } \\
\text { dilakukan } \\
\text { abutuhkan }\end{array}$ \\
\hline
\end{tabular}


perawat lupa atau tidak terpikir untuk mengimplementasikan langkah kebersihan tangan sesuai dengan Standar Prosedur Operasional (SPO) yang telah ditetapkan oleh rumah sakit.

Di setiap unit instalasi rawat inap RSUD Dr. R. Sosodoro Djatikoesoemo Bojonegoro terdapat poster pengingat terkait langkah kebersihan tangan (cuci tangan menggunakan cairan antiseptik berbasis alkohol dan cuci tangan menggunakan sabun dan air mengalir) yang sesuai dengan Standar Prosedur Operasional (SPO) yang telah

ditetapkan oleh rumah sakit. Namun pada poster tersebut belum ditambahkan informasi terkait takaran sabun dan cairan antiseptic berbasis alcohol yang seharusnya digunakan pada saat melakukan cuci tangan, selain itu juga belum adanya informasi terkait berapa lama proses kebersihan tangan yang seharusnya dilakukan dikarenakan proses cuci tangan menggunakan sabun dan air mengalir berbeda dengan lama waktu cuci tangan menggunakan cairan antiseptik berbasis alkohol.

Oleh karena itu, informasi yang kurang lengkap dalam poster kemungkinan dapat mempengaruhi tindakan perawat dalam implementasi kebersihan tangan sebelum dan sesudah pemasangan infus sesuai dengan Standar Prosedur Operasional (SPO) yang telah ditetapkan. Selain pentingnya komitmen dari perawat dalam implemenetasi SPO kebersihan tangan sesuai dengan aturan, juga perlunya dukungan yang lebih memadai dalam pemberian informasi prosedur kebersihan tangan secara lebih mendetail di setiap ruangan instalasi rawat inap oleh pihak rumah sakit.

Kebersihan tangan merupakan salah satu cara yang penting dalam mencegah terjadinya Phlebitis pada pasien yang terpasang infus. Pernyataan tersebut sesuai dengan penelitian yang dilakukan oleh (Hermawan, Junika and Nandeak, 2018) bahwa terdapat hubungan antara kepatuhan perawat dalam melaksanakan Standar Prosedur Operasional cuci tangan enam langkah lima momen (SPO) dengan kejadian Phlebitis, yang menunjukkan bahwa semakin tinggi kepatuhan perawat dalam melakukan cuci tangan enam langkah lima momen maka semakin rendah kejadian Phlebitis di rumah sakit. Hal tersebut juga sesuai dengan penelitian yang dilakukan oleh (Fatmawati dan Winarko , 2017) yang menyatakan bahwa jika perawat patuh dalam melakukan prosedur cuci tangan enam langkah lima momen dalam pemasangan infus sesuai deengan prosedur maka dapat mencegah transmisii organisme pada daerah penusukan jarum infus tidak terjadi, sehingga tidak terjadi phlebtis pada pasien yang dilakukan pemasangan infus.

Tabel 4. Hubungan Status Lokasi, Tanggung Jawab Personal, Legitimasi Figur Otoritas, Status Figur Otoritas dan Kedekatan Figur Otoritas dengan Kepatuhan Perawat dalam Implementasi SPO Kebersihan Tangan Sebelum dan Sesudah Pemasangan Infus di Instalasi Rawat Inap (IRNA) RSUD Dr. R.
Sosodoro Djatikoesoemo Bojonegoro tahun 2018

Kepatuhan Perawat

\begin{tabular}{|c|c|c|c|c|c|}
\hline \multirow{3}{*}{ Variabel } & \multicolumn{4}{|c|}{ Kepatuhan Perawat } & \multirow{3}{*}{$\begin{array}{l}\text { - Uji Chi } \\
\text { Square }\end{array}$} \\
\hline & \multicolumn{2}{|c|}{ Patuh } & \multicolumn{2}{|c|}{ Tidak Patuh } & \\
\hline & $\mathbf{N}$ & $\%$ & $\mathbf{n}$ & $\%$ & \\
\hline \multicolumn{6}{|l|}{ Status Lokasi } \\
\hline Baik & 17 & 53,1 & 15 & 46,9 & \multirow{3}{*}{0,178} \\
\hline Cukup & 5 & 26,3 & 14 & 73,3 & \\
\hline Kurang & 1 & 100,0 & 0 & 0,0 & \\
\hline
\end{tabular}

Tanggung

Jawab Personal

\begin{tabular}{lccccc} 
Baik & 21 & 55,3 & 17 & 44,7 & 0,020 \\
Cukup & 2 & 14,3 & 12 & 85,7 & \\
Kurang & 0 & 0,0 & 0 & 0,0 & \\
\hline
\end{tabular}

Legitimasi Figur

Otoritas

\begin{tabular}{lccccc} 
Baik & 13 & 52,0 & 12 & 48,0 & 0,178 \\
Cukup & 10 & 37,0 & 17 & 63,0 & \\
Kurang & 0 & 0,0 & 0 & 0,0 & \\
\hline
\end{tabular}

\begin{tabular}{|c|c|c|c|c|c|c|}
\hline $\begin{array}{l}\text { Status } \\
\text { Otoritas }\end{array}$ & Figur & & & & & \\
\hline Baik & & 15 & 65,2 & 8 & 34,8 & 0,015 \\
\hline Cukup & & 8 & 27,6 & 21 & 72,4 & \\
\hline Kurang & & 0 & 0,0 & 0 & 0,0 & \\
\hline
\end{tabular}

Kedekatan Figur

Otoritas

$\begin{array}{lcccc}\text { Baik } & 18 & 75,0 & 6 & 25,0 \\ \text { Cukup } & 4 & 19,0 & 17 & 81,0 \\ \text { Kurang } & 1 & 14,3 & 6 & 85,7\end{array}$

0,000

Kurang

Hubungan Status Lokasi dengan Kepatuhan Perawat dalam Implementasi SPO Kebersihan Tangan Sebelum dan Sesudah Pemasangan Infus

Menurut Milgram, Status of location atau status lokasi instruksi berhubungan dengan prestige tempat atau lokasi instruksi tersebut diberikan oleh figur otoritas (Griggs, 2017). Prestige adalah reputasi atau pengaruh yang dapat timbul dari keberhasilan, pangkat, prestasi, atau atribut lainnya yang menguntungkan sehingga dapat mempengaruhi seseorang untuk membuat keputusan (McLeod, 2007). Penilaian status of location dalam penelitian ini berkaitan dengan persepsi perawat terhadap prestige RSUD Dr. R. Sosodoro Djatikoesoemo Bojonegoro sebagai tempat kerja dan berkaitan dengan kebanggaan perawat terhadap prestasi yang telah dicapai oleh RSUD Dr. R. Sosodoro Djatikoesoemo Bojonegoro.

Berdasarkan Tabel 4 dapat diketahui hasil analisis berdasarkan uji statistik Chi Square dengan nilai $p$ sebesar $0,178 \quad(\alpha=0,05)$, sehingga menunjukkan bahwa status lokasi tidak berhubungan dengan kepatuhan perawat dalam implementasi SPO kebersihan tangan sebelum dan sesudah pemasangan infus. Hasil tabulasi silang dapat diketahui bahwa sebagian besar perawat memiliki prestige yang baik terhadap RSUD Dr. R. Sosodoro Djatikoesoemo Bojonegoro, namun proporsi perawat yang patuh dan tidak patuh dalam implementasi SPO kebersihan tangan jumlahnya cenderung seimbang sehingga dapat disimpulkan bahwa rasa bangga perawat terhadap rumah sakit belum tentu mempengaruhi tingkat kepatuhan perawat dalam implementasi SPO kebersihan tangan. 
Penelitian ini sesuai dengan penelitian yang dilakukan oleh (Gupita, 2016) menyatakan bahwa status lokasi tidak memiliki hubungan dengan kepatuhan perawat dalam menerapkan Standar Prosedur Operasional (SPO) pemasangan infus. Hal tersebut dikarenakan ada beberapa faktor lain yang secara langsung dapat mempengaruhi kepatuhan perawat dalam melaksanakan asuhan keperawatan sesuai dengan prosedur.

Hasil penelitian ini berbeda dengan penelitian yang dilakukan oleh (Ulum and Wulandari, 2013) yang menyebutkan bahwa terdapat hubungan yang siginifikan antara status of location dengan kepatuhan perawat dalam melakukan asuhan keperawatan. Peningkatan kepatuhan dapat terjadi karena persepsi yang baik serta rasa bangga perawat terhadap organisasinya. Prestige organisasi berhubungan positif dengan keterikatan pegawai terhadap organisasi. Semakin tinggi rasa bangga karyawan dengan prestasi organisasi semakin baik kinerja yang dilakukan karyawan terhadap organisasi tersebut. Kinerja yang baik merupakan hasil dari kepatuhan terhadap aturan dan prosedur yang berlaku serta instruksi atasan atau orang yang berpengaruh dalam suatu organisasi.

\section{Hubungan Tanggung Jawab Personal dengan Kepatuhan Perawat dalam Implementasi SPO Kebersihan Tangan Sebelum dan Sesudah Pemasangan Infus \\ Menurut Milgram, seseorang memiliki} automous state yaitu keadaan dimana seseorang sedang berada di bawah kendali orang lain namun seseorang tersebut memiliki hak dan kemampuan untuk membuat keputusan sendiri, hal tersebut menunjukkan bahwa seseorang harus mengambil tanggung jawab penuh atas apa yang dilakukannya, hal tersebut dapat didefinisikan sebagai personal responsibility (Griggs, 2017). Tanggung jawab personal bertujuan untuk mengasumsikan tanggung jawab atas tindakan yang dilakukan dan dapat menunjukkan disiplin dari individu terhadap suatu keputusan yang diambil. Penilaian personal responsibility dalam penelitian ini berkaitan dengan tanggung jawab perawat dalam implementasi tindakan dan langkah kebersihan tangan sebelum dan sesudah pemasangan infus sesuai dengan Standar Prosedur Operasional (SPO) yang telah ditetapkan oleh RSUD Dr. R. Sosodoro Djatikoesoemo Bojonegoro.

Berdasarkan Tabel 4 dapat diketahui hasil analisis menggunakan uji statistik Chi Square dengan nilai $p$ sebesar $0,020(\alpha=0,05)$, sehingga menunjukkan bahwa tanggung jawab personal mempunyai hubungan yang signifikan dengan kepatuhan perawat dalam implementasi SPO kebersihan tangan sebelum dan sesudah pemasangan infus. Hasil tabulasi silang menunjukkan bahwa semakin baik tingkat tanggung jawab personal maka terdapat kecenderungan terhadap peningkatan kepatuhan perawat dalam implementasi Standa Prosedur Operasional (SPO) kebersihan tangan sebelum dan sesudah pemasangan infus.

Hasil penelitian tersebut sesuai dengan penelitian yang dilakukan oleh (Jeli and Ulfa, 2014), bahwa dengan adanya tanggung jawab yang baik dari karyawan dapat berpengaruh terhadap peningkatan kinerja terutama dalam hal kepatuhan dalam melaksanakan suatu prosedur dikarenakan tanggung jawab berkaitan dengan komitmen seseorang terhadap apa yang telah ditetapkan. Personal responsibility dianggap sebagai sesuatu yang harus atau wajib dilakukan dan dikerjakan. Oleh karena itu adanya personal responsibility yang baik dari perawat dapat meningkatkan kepatuhan dalam melakukan kebersihan tangan sesuai dengan SPO yang telah ditetapkan oleh rumah sakit.

Hasil penelitian ini diperkuat oleh (Cialdini and Martin, 2004) yang menyatakan bahwa dalam prinsip komitmen atau konsistensi, jika seseorang telah berkomitmen untuk mengikatkan diri pada suatu posisi atau suatu tindakan maka seseorang tersebut akan lebih mudah memenuhi permintaan yang sesuai dengan komitmen yang telah disepakati. Selain itu penelitian ini didukung oleh penelitian yang dilakukan oleh (Ulum and Wulandari, 2013) bahwa terdapat hubungan antara personal responsibility (tanggung jawab personal) dengan kepatuhan perawat dalam melaksanakan asuhan keperawatan. Jika tanggung jawab perawat dalam melaksanakan asuhan keperawatan baik maka tingkat kepatuhan perawat dalam melaksanakan asuhan keperawatan juga akan baik. Namun hasil penelitian ini berbeda dengan penelitian yang dilakukan oleh (Sumaningrum, 2015) yang menyebutkan bahwa tidak terdapat hubungan yang signifikan antara tanggung jawab dengan kepatuhan perawat dalam mencuci tangan.

Hubungan Legitimasi Figur Otoritas dengan
Kepatuhan Perawat dalam Implementasi SPO
Kebersihan Tangan Sebelum dan Sesudah
Pemasangan Infus
Legitimasi figur otoritas (Legitimacy of authority figure) berkaitan dengan tanggapan seseorang dalam menerima dan mengakui kewenangan, keputusan, atau kebijakan yang ditetapkan oleh seorang pimpinan atau figur otoritas. Menurut penelitian yang dilakukan oleh Milgram, sekelompok orang cenderung untuk memenuhi perintah dari orang lain jika mereka mengenal otoritas mereka dengan baik secara moral maupun hukum yang berlaku (Griggs, 2017). Penilaian legitimacy of authority figure dalam penelitian ini berkaitan dengan persepsi perawat terhadap kepala ruangan yang dianggap sesuai dengan jabatan yang dimiliki sehingga legal dan berhak untuk mengatur dan memberikan perintah kepada perawat.

Berdasarkan Tabel 4 dapat diketahui hasil analisis menggunakan uji statistik Chi Square dengan nilai $p$ sebesar $0,178(\alpha=0,05)$, sehingga menunjukkan bahwa legitimasi figur otoritas tidak berhubungan dengan kepatuhan perawat dalam implementasi SPO kebersihan tangan sebelum dan sesudah pemasangan infus. Sehingga dapat disimpulkan bahwa kepala ruagan yang dianggap 
sebagai figur otoritas dan legal dalam memberikan kewenangan terkait pelaksanaan SPO kebersihan tangan tidak berdampak terhadap kepatuhan perawat dalam implementasi SPO kebersihan tangan sebelum dan sesudah pemasangan infus.

Hasil penelitian ini sejalan dengan penelitian yang dilakukan oleh (Mahfudhoh and Rohmah, 2015) bahwa peningkatan tingkat kewenangan (legalitas) figur otoritas tidak memberikan dampak yang signifikan terhadap peningkatan kepatuhan penulisan resep sesuai dengan formularium. Namun hasil penelitian ini berbeda dengan penelitian yang dilakukan oleh (Ulum and Wulandari, 2013) yang menunjukkan bahwa terdapat hubungan antara legitimacy of authority figure dengan kepatuhan perawat dalam asuhan keperawatan yaitu perawat yang memiliki persepsi sedang terhadap legalitas kepala ruangan sebagai atasan yang sah dalam memberian asuhan keperawatan sehingga hal tersebut meningkatkan kepatuhan perawat dalam memberikan asuhan keperawatan.

\section{Hubungan Status Figur Otoritas dengan Kepatuhan Perawat dalam Implementasi SPO Kebersihan Tangan Sebelum dan Sesudah Pemasangan Infus \\ Status figur otoritas (status of authority} figure) berkaitan dengan kedudukan sosial dari figur otoritas dalam pandangan seseorang. Bawahan dapat mengakui kekuasaan figur otoritas jika figur otoritas tersebut mempunyai keahlian dalam bidang tersebut melebihi pengetahuan dan keahliannya sendiri. Penilaian status of authority figure dalam penelitian ini berkaitan dengan persepi perawat terhadap keterampilan, kemampuan, pengetahuan dan profesionalitas kepala ruangan di rumah sakit.

Berdasarkan Tabel 4 dapat diketahui hasil analisis menggunakan uji statistik Chi Square dengan nilai $p$ sebesar $0,015(\alpha=0,05)$, sehingga menunjukkan bahwa status figur otoritas mempunyai hubungan yang signifikan dengan kepatuhan perawat dalam implementasi SPO kebersihan tangan sebelum dan sesudah pemasangan infus. Hasil penelitian ini sesuai dengan sesuai dengan penelitian yang dilakukan oleh Milgram bahwa seseorang cenderung lebih patuh jika yang memberikan perintah adalah orang yang lebih professional dan memiliki pengetahuan yang lebih tinggi. Serta diperkuat dengan penelitian yang dilakukan oleh (Ulum and Wulandari, 2013) bahwa status figur otoritas mempengaruhi kepatuhan pendokumentasian asuhan keperawatan.

Berdasarkan hasil tabulasi silang dapat disimpulkan bahwa mayoritas perawat yang memiliki persepsi bahwa kepala ruangan merupakan figur yang profesional dan memiliki pengetahuan serta pengalaman yang lebih baik dapat mempengaruhi tingkat kepatuhan perawat dalam implementasi SPO kebersihan tangan sebelum dan sesudah pemasangan infus. Status kepala ruangan yang lebih tinggi cenderung membuat perawat untuk memenuhi perintahnya. Menurut (Fattori et al., 2015) status otoritas seorang pimpinan memiliki peran penting dan sentral dalam mempengaruhi kepatuhan dan ketidakpatuhan seseorang dalam melakukan suatu hal.
Berdasarkan hasil penelitian dapat disimpulkan bahwa mayoritas perawat yang memiliki persepsi bahwa kepala ruangan memiliki status of authority figure yang baik cenderung lebih patuh dalam implementasi Standar Prosedur Operasional (SPO) kebersihan tangan, hal tersebut kemungkinan disebabkan karena perawat merasa bahwa kredibilitas, integritas, keahlian dan pengetahuan kepala ruangan dianggap lebih baik sehingga mendorong perawat untuk patuh dalam impelementasi SPO kebersihan tangan sebelum dan sesudah pemasangan infus.

\section{Hubungan Kedekatan Figur Otoritas dengan Kepatuhan Perawat dalam Implementasi SPO Kebersihan Tangan Sebelum dan Sesudah Pemasangan Infus}

Figur otoritas memiliki peran penting dalam menjalin hubungan dengan bawahannya. Semakin dekat figur otoritas dengan bawahannya maka semakin tinggi tingkat kepatuhan bawahan tersebut sesuai dengan perintah yang diberikan. Semakin penting seseorang bagi orang lain maka akan semakin besar pengaruh yang dimiliki oleh seseorang tersebut dalam pengambilan keputusan (McLeod, 2007). Penilaian Kedekatan Figur Otoritas (proximity of authority figure) berkaitan dengan persepsi perawat terhadap kedekatan hubungan yang terjalin antara perawat dengan kepala ruangan dalam implementasi SPO kebersihan tangan sebelum dan sesudah pemasangan infus.

Berdasarkan Tabel 4 dapat diketahui hasil analisis menggunakan uji statistik Chi Square dengan nilai $p$ sebesar $0,000(\alpha=0,05)$, sehingga menunjukkan bahwa kedekatan figur otoritas mempunyai hubungan yang signifikan dengan kepatuhan perawat dalam implementasi SPO kebersihan tangan sebelum dan sesudah pemasangan infus. Sehingga dapat disimpulkan bahwa semakin dekat hubungan perawat dengan kepala ruangan, maka semakin tinggi tingkat kepatuhan perawat dalam implementasi SPO kebersihan tangan.

Hasil penelitian ini sesuai dengan penelitian yang dilakukan oleh Milgram bahwa semakin dekat hubungan bawahan dengan sosok otoritas maka semakin tinggi pula tingkat kepatuhannya (Griggs, 2017). Hasil penelitian ini diperkuat oleh penelitian (Gupita, 2016) bahwa terdapat hubungan yang siginifikan antara kedekatan figur otoritas dengan kepatuhan perawat melaksanakan SPO pemasangan infus. Dalam penelitian ini kedekatan kepala ruangan dan perawat mengakibatkan hubungan yang baik diantara keduanya, sehingga perawat akan lebih segan untuk melaksanakan SPO kebersihan tangan dengan baik sesuai dengan instruksi atau perintah dari kepala ruangan.

Kedekatan antara atasan dan bawahan yang tinggi dapat membawa dampak yang positif dala peningkatan kepatuhan bawahan. Hubungan atau kedekatan yang baik antara kepala ruangan dengan perawat dapat memungkinkan seorang perawat lebih mematuhi permintaan, arahan dan saran dari kepala ruangan. Kehadiran kepala ruangan untuk memberikan arahan dan saran merupakan salah 
satu bentuk kedekatan antara kepala ruangan dan perawat pelaksana di Instalasi Rawat Inap.

Kedekatan antara atasan dan bawahan dapat semakin bedampak positif dalam peningkatan kepatuhan perawat dalam iplementasi Standar Prosedur Operasional (SPO) kebersihan tangan sebelum dan sesudah pemasangan infus jika kepala ruangan juga melakukan supervisi dan pengawasan terhadap perawat, sehingga kepala ruangan secara langsung dapat menilai tingkat kepatuhan perawat. Pernyataan tersebut sesuai dengan penelitian yang dilakukan oleh (Dewi and Ria, 2017) yang menyebutkan bahwa adanya supervisi dan pengawasan dapat meningkatkan kepatuhan perawat dalam melaksanakan kebersihan tangan.

\section{SIMPULAN}

Kesimpulan yang dapat diambil dari penelitian ini adalah $55,8 \%$ perawat di Instalasi Rawat Inap (IRNA) RSUD Dr. R. Sosodoro Djaikoesoemo Bojonegoro tidak patuh dalam implementasi Standar Prosedur Operasional (SPO) Kebersihan Tangan sebelum dan sesudah pemasangan infus. Hasil penilaian menunjukkan bahwa sebagian besar perawat tidak melakukan langkah kebersihan tangan dengan sempurna pada saat melakukan 6 langkah cuci tangan yaitu menggosok punggung jari-jari pada telapak yang berlawan dengan jari-jari saling mengunci $(57,7 \%)$, menggosok secara memutar pada ibu jari kiri dengan tangan kanan mengunci pada ibu jari tangan kiri dan sebaliknya $(37,5 \%)$ dan menggosok ujung kuku jari kiri secara memutar pada telapak tangan kanan dan sebaliknya (25,9\%).

Berdasarkan hasil uji statistik Chi Square didapatkan hasil bahwa terdapat hubungan yang signifikan antara tanggung jawab personal, status figur otoritas dan kedekatan figur otoritas dengan kepatuhan perawat dalam implementasi Standar Prosedur Operasional (SPO) kebersihan tangan sebelum dan sesudah pemasangan infus di Instalasi Rawat Inap (IRNA) RSUD Dr. R. Sosodoro Djatikoesoemo Bojonegoro, sedangkan variabel status lokasi dan legitimasi figur otoritas tidak memiliki hubungan yang signifikan dengan kepatuhan perawat dalam implementasi SPO kebersihan tangan sebelum dan sesudah pemasangan infus di Instalasi Rawat Inap (IRNA) RSUD Dr. R. Sosodoro Djatikoesoemo Bojonegoro.

\section{DAFTAR PUSTAKA}

Asiye D. Akyol (2007) 'Hand hygiene among nurses in Turkey: opinions and practices', Journal of Clinical Nursing, 16(3), pp. 431-7. Available at:

https://www.ncbi.nlm.nih.gov/pubmed/17335 518.

Cialdini, R. B. and Martin, S. (2004) The science of compliance, British Cardiovascular Society. doi: 10.1007/978-90-481-2350-6.

Dewi, R. R. K. (2017) 'Faktordeterminan Kepatuhan
Perawat Dalam Melakukan Praktik Cuci Tangan Di RSUD Ade Muhammad Djoen Sintang', Jurnal Kesehatan Masyarakat Khatulistiwa, 4(3), pp. 232-237. Available at: http://openjurnal.unmuhpnk.ac.id/index.php/J $\mathrm{KMK} /$ article/view/865/687.

Fatmawati, L. and Winarko, H. (2017) 'Kepatuhan Cuci Tangan Dapat Menghambat Terjadinya Plebitis Pada Proses Pasca Pemasangan Infus (Handwashing Compliance May Inhibit Plutitis Occurrence Post-Infusion Installation Process)', Journals of Ners Community, 8(2), pp. 123-132. Available at: https://journal.unigres.ac.id/index.php/JNC/ar ticle/view/407/328.

Fattori, F. et al. (2015) 'Authority relationship from a societal perspective: Social representations of obedience and disobedience in Austrian young adults', Europe's Journal of Psychology. PsychOpen, a publishing service by Leibniz Institute for Psychology Information (ZPID), Trier, Germany (www.zpid.de)., 11(2), pp. 197-213. doi: 10.5964/ejop.v11i2.883.

Gorski, L. et al. (2016) 'Infusion therapy standards of practice', Journal of Infusion Nursing, 39(1S), pp. S1-S159.

Griggs, R. (2016) 'Milgrams Obedience Study: A Contentious Classic Reinterpreted', Teaching of Psychology, 44(1).

Gupita, C. A. R. (2016) Faktor Yang Berhubungan Dengan Kepatuhan Perawat Dalam Melaksanakan Standar Prosedur Operasional Pemasangan Infus (Studi Di Rumah Sakit Umum Haji Surabaya). Universitas Airlangga. Available at: http://repository.unair.ac.id/id/eprint/46660.

Hermawan, D., Junika, E. and Nadeak, J. (2018) 'Hubungan Kepatuhan Perawat Melaksanakan Standar Prosedur Operasional (SPO) Cuci Tangan Terhadap Kejadian Phlebitis Di Rumah Sakit Graha Husada Bandar Lampung Tahun 2018', Holistik Jurnal Kesehatan, 12(3), pp. 196$204 . \quad$ Available at: http://ejurnal.malahayati.ac.id/index.php?jour nal=hlstk\&page $=$ article \&op $=$ view \&path $\% 5 B$ $\% 5 \mathrm{D}=1230 \&$ path\%5B\%5D=1110.

Jeli, M. M. and Ulfa, M. (2014) 'Kepatuhan Perawat dalam Melaksanakan Standar Prosedur Operasional Pemasangan Infus di Rumah Sakit PKU Muhammadiyah Gombong', Mutiara Medika, 14(1), pp. 51-62. Available at: http://journal.umy.ac.id/index.php/mm/article/ view/2471/2451.

Mahfudhoh, S. and Rohmah, T. N. (2015) 'Faktor Yang Mempengaruhi Kepatuhan Penulisan Resep Sesuai Formularium', Jurnal Administrasi Kesehatan Indonesia, 3(1), pp. 21-30. Available at: https://ejournal.unair.ac.id/JAKI/article/view/1486/114 6.

McLeod, S. (2007) Obedience to Authority, Simply Psychology. Available at: https://www.simplypsychology.org/obedience 
.html (Accessed: 8 June 2018)

Nursalam (2011) Manajemen Keperawatan: Aplikasi dalam Praktik Keperawatan Profesional. 3rd edn. Surabaya: Salemba Medika. Available at: https://ners.unair.ac.id/materikuliah/BUKUMANAJEMEN-2011.pdf.

Sumaningrum, N. D. (2015) Faktor Yang Berhubungan Dengan Kepatuhan Perawat Mencuci Tangan Handrub Pada Saat Pemasangan Infus Di Rumah Sakit X Di Jawa Timur, Repository Universitas Airlangga. Universitas Airlangga. Available at: http://repository.unair.ac.id/29493/.

Ulum, M. M. and Wulandari, R. D. (2013) 'Faktor Yang Mempengaruhi Kepatuhan Pendokumentasian Asuhan Keperawatan Berdasarkan Teori Kepatuhan', Jurnal Administrasi Kesehatan Indonesia, 1(3), pp. 252-262. 